\title{
MACROPRUDENTIAL POLICY ON BANKING SECTOR IN INDONESIA
}

\author{
${ }^{1}$ Feny Putri Emyliani \\ ${ }^{2}$ Dwi Wulandari \\ dwi.wulandari.fe@um.ac.id \\ ${ }^{4}$ Bagus Shandy Narmaditya \\ Faculty of Economics, Universitas Negeri Malang \\ Jl. Semarang No.5, Kota Malang 65145, Indonesia \\ ${ }^{3}$ Siti Rosnita Binti Sakarji \\ Universiti Teknologi MARA (UiTM) Melaka \\ Kampus Alor Gajah, Km 26 Jalan Lendu, 78000 Alor Gajah, Melaka, Malaysia
}

received: 27/03/18; revised: 02/05/18; published: 27/06/18

\begin{abstract}
This study investigates the implementation of macroprudential policy on banking sector and society. The research applied a descriptive analysis by using an in-depth interview with Bank Indonesia, representative of commercial bank, and society. The result showed that macroprudential policy has no impact on individual, but it had an impact on industrial banking specifically on bank credit lending which caused by LTV regulation. The society responses to the LTV policy is that the majority do not object to the imposition of a maximum limit for housing credit enacted by bank because of the relatively long credit period. Furthermore, another instrument of macroprudential such as GWM-LFR does not have an impact on banking sector and society but capital buffer instrument assuming a sluggish economy condition is assessed to have an impact on lending by banks.
\end{abstract}

Keywords: capital buffer; macroprudential policy; LTV; GWM-LFR

\section{INTRODUCTION}

The implementation of macroprudential policy in Indonesia is a consequence of the economic crisis in the past. The economic crisis in 1998 due to the decreasing number of investor's trust and spread to other sectors such as financial and banking sectors. The biggest point of the economic crisis in Indonesia involved larger number of banks declared as failed banks and decreased trust from society (Syafi'i \& Ruslina, 2016; Suteja \& Ginting, 2017). The worst condition happens when they withdraw funds simultaneously in a huge amount that caused lack of liquidity of bank and create a shock in a financial system. Macroprudential policy is formed for the stability of financial system purpose (Vucinic, 2016). Galati \& Moessner (2011) explained that macroprudential policy has a purpose to limit the risk and cost from systemic crisis. Macroprudential policy simply is the implementation of prudential principles in financial system to maintain the balance between macroeconomics and microeconomics goals (Bank Indonesia, 2016).

More specifically, macroprudential policy have two main objectives which are strengthen the resilience of the financial system, and actively limit the build- up of systemic financial risks (Gadanecz \& Jayaram, 2015). Furthermore, Vergara (2015) mentioned that macroprudential policy is a policy aimed at preserving financial stability. Macroprudential instruments are typically introduced with the objective of reducing systemic risk, either over time or across institutions and markets. Countries use a variety of tools, including credit-related, liquidity-related, and capital-related measures to address such risks, and the choice of instruments often depends on countries' degree of economic and financial development, exchange rate regime, and vulnerability to certain shocks. Countries often use these instruments in combination rather than simply use them to complement other macroeconomic policies, and adjust them counter cyclically so that they act in the same way as automatic stabilizers (Lim et al., 2011). Meanwhile, Bruno \& Hyun (2013) explained that macroprudential instruments are aimed at first, the procyclical behavior of the financial system and second, the common exposure in which the instrument is used as a prudential rule on each banking institution.

The implementation of macroprudential policy in several countries has given significant impact. The country among them is Latin America where central 
banks proactively used Reserve Requirements (RRs) with countercyclical behavior to manage credit cycle and liquidity in maintaining financial system stability (Tovar, Escribano \& Martin, 2012). In South Korea, based on Bruno \& Shin (2014) research, the Korean government has introduced a new macroprudential policy to improve capital flows and financial stability. The result both of them found that capital flows to Korea became less sensitive to global factor after the implementation of macroprudential policy. The other research conducted by Lee, Asunction \& Kim (2015), found that there is two significant discoveries appears, generally, macroprudential policy indeed can stimulate financial stability in Asia.

Various types of macroprudential policy are more effective to many kinds of macroeconomic risks. Some of the analysis results are People's Republic of Chinastated RC Bank and Chinese Banking Regulatory Commission launch macroprudential instrument simultaneously and the result shows strict macroprudential related to credit can decrease credit expansion quickly and slowly reduce the increase in house price but it does not affect the growth of leverage. The result of LTV policy to property prices has more noticeable effect than leverage and credit growth. In Hong Kong, China higher transaction tax collected by government apparently more effective in hampering house demand and restraining the growth of house prices. However, both of these policies occurred in short-term.

The third place of developing country is Thailand with its tendency to restrict macroprudential. As the result, policies related to credit is judged to have small impacts in increasing house price, it has no significant effect on credit but has direct impact on leverage. Claessens, Ghosh \& Mihet (2014) also gives the result that steps to increase the growth of banking assets is found, there is confirmation in Debt to Income Ratio (DTI) and LTV for borrowers while there is limitation in credit growth and foreign exchange currency for financial institutions. In the other hand, Capital Buffer has small impact in assets growth. In Indonesia, there are numerous studies related to macroeconomic policy such as Swaningrum \& Hariawan (2014) showed that LTV and GWM LDR variables have not effectively resolve credit pro cyclicality in banking. In addition, Qudrati \& Suriani (2016) remarked that macroprudential policy instrument implemented by Bank Indonesia affects the risk of nonperforming loans. Macroprudential policy in Indonesia directed to control lending and macroprudential instrument which targeting capital and lending sides. This is the performance of bank lending and after the implementation of Indonesian macroprudential policy in terms of local banking point of view in Figure 1 and national industrial banking (See Figure 2).
Distribution of Banking Funds in Indonesia (Billion IDR)

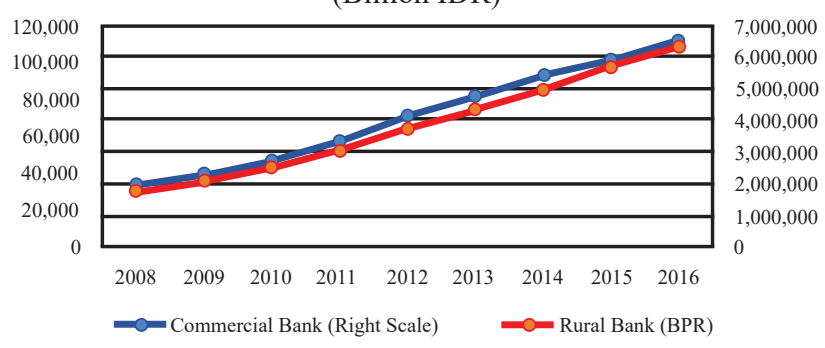

Source: Regional Economic Studies in East Java

Figure 1. Performance of Commercial Banks and BPR in East Java

Figure 1 provides the distribution of banking funds which is divided into two namely commercial bank and rural bank (BPR). In general, both showed an upward trend during period. In 2008, when Indonesia trucked by global crisis, the bank lend was about IDR 2015 trillion for commercial banks, and IDR 31 trillion for BPR. It rose dramatically until 2016 when bank successfully distributed funds in amount of IDR 6,500 trillion for commercial banks and IDR 109 trillion for BPR. The growth of banking funds distribution showed the increasing number by approximately 322 per cent in commercial banks and 351 percent in BPR to the end of period.

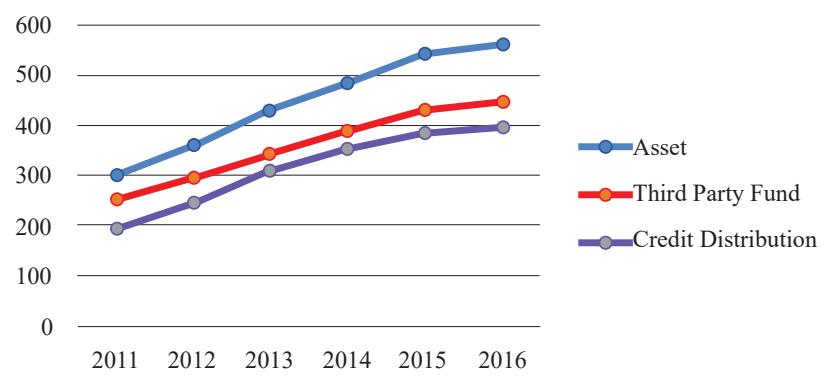

Source: Statistics Banking Indonesia, OJK (processed)

Figure 2. Banking Funds Distributions in Indonesia 2008-2016

Figure 2 illustrates the banking funds in Indonesia between 2008 to 2016. In more detail, East Java is one of the provinces with high economic activity which grows 5.2 per cent in third quarter 2017 (yoy) and continue gradually increased in second quarter 2017 (5.1\%). The Inflation rate in East Java is in the third place after Banten (4.17\%) and West Java (3.87\%) was about $3.84 \%$ in third quarter 2017, it is higher than national inflation which reaching out by approximately $3.72 \%$ (yoy). Malang is one of regions in East Java which contributed to the inflation rate in East Java, inflation rate of Malang (yoy) is about 3.80 and become the second position being lower than Surabaya. Based on the high economic activity in Malang, it high possibility affect to the growth of credit distribution in banking. Therefore, this research aims to explore in East Java 
especially Malang whether macroprudential policy has an impact on banking sector and society.

\section{METHOD}

The research applied a descriptive analysis method by using an in-depth interview with Bank Indonesia Malang, representative of commercial bank and society. The outline of questions were about (1) the impact of macroprudential implementation to the banking sector, (2) the implementation of macro-prudential policy that affect to banking tasks as intermediary institutions, (3) the macroprudential instruments that has a significant impact to banking activity. Meanwhile the questions asked to society are (1) the response of society with the regulation about setting credit maximum limit or financing which given by bank for mortgage loans, and (2) the society have objections and looking for motive to purchase house, is it for living, investment, or other purpose. The number of respondent for this research is two persons from the representative of Bank Indonesia in Malang, local banking financial institutions and fifteen people from the society. The reason why the researcher chose Bank Indonesia (BI) Malang is that BI is the regulator of this policy so this is considered as the right steps to investigate the information about how far this policy implemented until today. Criteria to choose the two bank (BUMN) because has big market share and reputation. The researcher studied 15 respondents to asked about the policy of credit limit for house ownership. The criteria researcher is if the respondents are or already has complete mortgage loans. This research also has limitations where the name of banks cannot be mentioned because it is related to the reputation and to keep the trust of society in banking so it can only symbolize with code.

\section{RESULTS}

Macroprudential instruments that implemented in Indonesia are the Loan to Value (LTV), GWM-Loan to Funding (LFR) and Countercyclical Capital Buffer. LTV policy is taken to control mortgage price level and set the amount of DP for the vehicle loan.

Table 1. Modification of Self Financing and Number of Property Loans PT. Bank X (persero), Tbk

\begin{tabular}{lcc}
\hline \multicolumn{1}{c}{ Information } & Self Financing & $\begin{array}{c}\text { Number of } \\
\text { Property Loans }\end{array}$ \\
\hline Before LTV 2011 & $5 \%-10 \%$ & 18.1 Trillion \\
After LTV 2012 & $30 \%$ & 25.3 Trillion \\
Post easing LTV 2016 & $10 \%-15 \%$ & 36.4 Trillion \\
\hline
\end{tabular}

Source: Annual Report PT Bank X (persero), Tbk

Table 1 explains the modification of self financing and number of property loan PT. Bank X (persero), Tbk. In general, there are showed a remarkably changes by implementing Loan to Value (LTV). It was about
5 per cent and 10 per cent before LTV implemented and it rose dramatically to approximately 30 per cent after implemented. Meanwhile, the number of property loans showed an increase trend during the period. It was 18.1 trillion rupiah in the beginning of periods, it rose almost doubled 25.3 trillion rupiah then continue increased in the end of period.

Table 4. Modification of Self Financing and Number of Property Loans PT Bank Y (persero), Tbk

\begin{tabular}{lcc}
\hline \multicolumn{1}{c}{ Information } & Self Financing & $\begin{array}{c}\text { Number of } \\
\text { Property Loans }\end{array}$ \\
\hline Before LTV 2011 & $5 \%-10 \%$ & 9.49 Trillion \\
After LTV 2012 & $30 \%$ & 9.90 Trillion \\
Post easing LTV 2016 & $10 \%-15 \%$ & 18.80 Trillion \\
\hline Source: Annual Report PT Bank Y (persero), Tbk
\end{tabular}

Table 4 informs the modification of self financing and number of property loan in PT Bank Y (persero), tbk. In more detail, the percentages of self financing showed indifferent result between PT. Bank X and PT. Bank Y. However, it showed noticeable number of property loans compared to PT. Bank X. It was about 9.49 trillion rupiah before LTV implemented then it rose slightly after implemented by approximately 0.50 trillion rupiah and reaching out the highest achievement in the end of period by approximately 18.80 trillion rupiah.

The Development of Consumer Credit

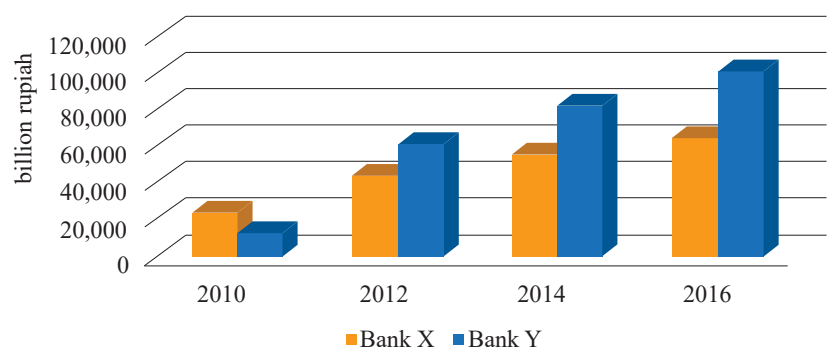

Source: Annual Report of each bank (processed)

Figure 3. The Development of Consumer Credit

Figure 3 provides information about the development of consumer credit during period 2010 and 2016. Overall, both banks experienced an upward trend. In 2010, Bank Y was about 10,000 billion rupiah being lower than Bank X, but it outraced in the next three years and reaching out almost 100,000 in 2016. Bank X was under 50,000 billion rupiah in 2012 and continue to rise in the next two years by approximately 50,000 billion rupiah and slightly more 50,000 billion rupiah respectively.

The instrument that has an impact on the society is the LTV policy. Figure 4 showed the society responses about the implementation of credit. From 15 respondents, most of them answered no objection in the implementation of credit amount regulation or financing which can 
be distributed by a bank that is at the beginning of implementation is 70 per cent, automatically people have to do self-financing or prepare 30 per cent in advance and 67 per cent of respondents revealed that they did not object to the rules for relatively similar reasons because of the long credit period. The work background of the respondents is with sufficient income so that this regulation will not be a burden for their financial. Figure 5 illustrates the findings of motives in buying property. As much as 100 per cent people answered that it will be a residence, despite the fact that when the researchers investigate directly to the address submitted by the respondent some of the houses are rented by someone else. Activities like this are feared will trigger a rise in property prices.

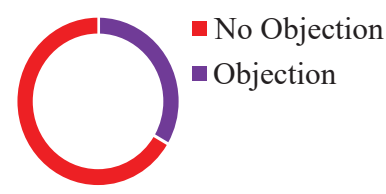

Figure 4. Society's Respons

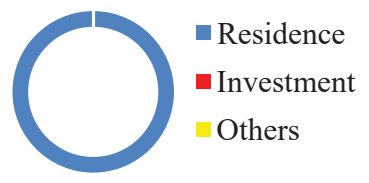

Figure 5. The motives of Buying Property
The next macroprudential instrument is the GMWLoan to Funding Ratio (GWM-LFR). The results of this study show that banks are not affected by the ratio of GWM-LFR due to LFR provisions of the bank if it is within the range of LFR target then the GWM-LFR is 0 per cent of the TPF in rupiah. LFR target is at 80 per cent for the lower limit and 92 per cent for the upper limit. This means that if the LFR bank is between 80 per cen - 92 per cent then the amount of GWM-LFR filled by a bank is 0 per cent of TPF. The amount of LFR in each of PT Bank X (Persero), Tbk and PT Bank Y (Persero), Tbk in 2016 are 89 per cent and 85 per cent respectively. LFR banks are still within the upper and lower limits of the LFR so that the GWM-LFR met by the bank is 0 per cent. That way banks have no obligation to meet the GWM-LFR so as not to affect the liquidity and lending bank.

Household Consumption (\%)

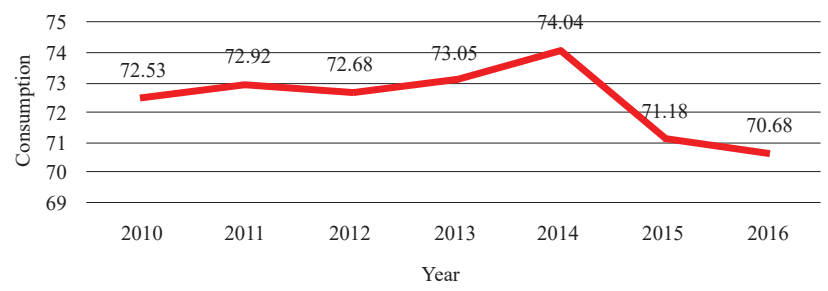

Figure 6. Household Consumption Source: BPS Malang

The society consumption level of Malang from year to year based on GRDP with expenditure approach (figure 6) has increased from 2010 until 2014 and then decreased until 2016.

Figure 6 explains the percentages of household consumption during 2010 and 2016. Overall, Household consumption still occupies the highest positions of GRDP distribution with expenditure approach. This indicates that the society of Malang have high purchasing power which reflects an economy is in a stable condition. OJK noted that the credit growth of the banking industry in 2016 as a whole is a single digit.

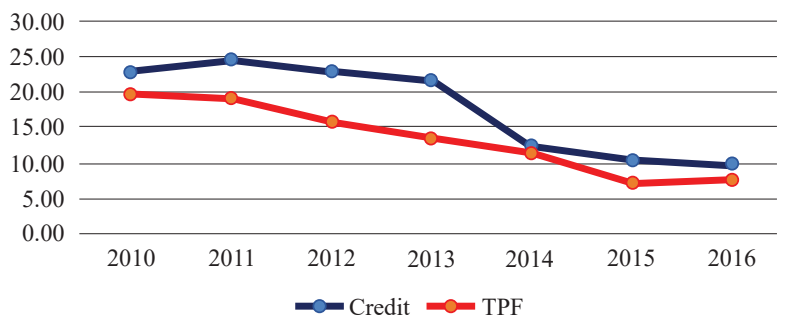

Figure 7. Credit Growth and TPF National Banking 2010-2016

Figure 7 provides credit growth and TPF national banking in 2010 to 2016. In 2010, credit growth of 22.80 per cent (yoy) further increased in 2011 by 24.59 per cent. From 2012 to 2016 credit growth has decreased continuously to the level of 9.60 per cent. Overall, the banking industry has been affected by the macroprudential policy, especially the tightening of LTV regulation so that its credit distribution growth is decreasing. In addition, the decrease of lending is also caused by the decrease of TPF growth. In order to maintain bank LDR ratio, this adjustment is made and to keep LFR banking in the range of lower limit and an upper limit of LFR set by BI.
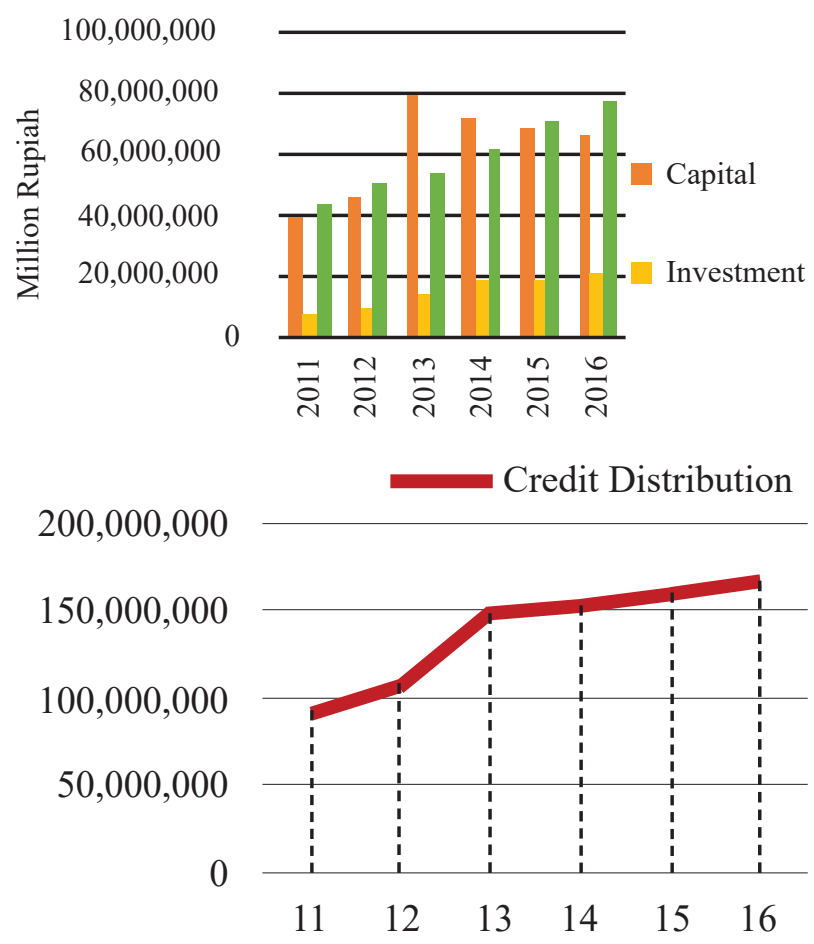

Figure 8 . The amount of lending by a commercial bank and BPR in Malang. 
Figure 8 showed the amount of lending by a commercial bank and BPR in Malang. In general, the total credit of banks experienced an upward trend and it is dominated by types of consumer loans. This proves that if the assumption of the economy is currently sluggish so the CCB rule is still 0 per cent then proven to increase the lending of banks. However, due to the fact that society still have high purchasing power, high consumption levels indicate the economy is in good condition make CCB rules need to be evaluated, because the higher bank lending, feared in the future if the economy is disturbed, the economy can fall and accompanied by the bank's perceived losses due to credit risks. As a result, there will be other risks that will make the banking situation more difficult. The downfall is due to all banks have the same credit concentration that is in consumer credit where consumption activity is an activity that has no guarantee of future income as well as investment activity or other business.

\section{DISCUSSION}

The change of self-financing scale is caused by the implementation of LTV does not affect the amount of property loans is distributed by PT Bank X (Persero), Tbk. This is because PT Bank X (Persero) targets the middle and high-income communities so it is relatively unaffected by the LTV policy. Besides, PT Bank X (Persero), Tbk is also active in property exhibition activities as one of property product marketing strategy. Recorded in 2016 PT Bank X (Persero) is re-trusted for the 6th time becoming Official Bank in the largest property exhibition event in Indonesia held by Real Estate Indonesia (RET).

The number of property loans (before the implementation of LTV) was about IDR 9.49 trillion in 2011 being higher than the previous year in 2010 of IDR 8.13 trillion and IDR 4.57 trillion in 2009. This product was well considered because mortgage loan product in PT Bank X (Persero), Tbk was started in 2007. This is a good achievement considering mortgage loan product has been running for several years. It can be seen that in the year of the implementation of LTV, property loan grow approximately 4.3 per cent. This indicates that PT Bank Y (Persero), Tbk actually holds the principle of prudence in credit distribution, especially property that has just been granted. Before reaching the number of IDR 9.90 trillion, recorded that as of June 2012 the distribution of loan was about IDR 8.7 trillion. The business focus of PT Bank Y (Persero), Tbk not only concentrated in property sector credit but also more on financing or microcredit. However, the easing of LTV conducted by BI makes the amount of property loans disbursed by these banks is doubled increased.

Beside to focusing on housing loans, LTV is also targeting motor vehicle loans (KKB). KKB is also included in consumer credit. The development of consumer loans from year to year from both BUMN banks can be seen in figure 1. The figure showed that consumer credit in both Bank experience an upward trend from the begining to the end of period. In the middle of 2012 BI set LTV to control the amount of credit or financing in the property sector and the amount of DP KKB does not stop the banking to keep capturing its market so that it can close the end of 2012 with the amount of credit is dominated by KPR and KKB is for each bank, PT Bank X (Persero), Tbk and PT Bank Y (Persero) Tbk, amounted to IDR 43.9 trillion and IDR 61.5 trillion.

The last instrument is an instrument with a capital target. Countercyclical Capital Buffer is formed with the purpose of banks are required to save or create capital reserves at a time when the economy is being well with the aim of going to continue to lend when the economy is weakening. The rate determined by $\mathrm{BI}$ in relation to this $\mathrm{CCB}$ policy is $0 \%-2.5 \%$ in which the evaluation will be conducted by BI every 6 months. From the beginning of application until now the $\mathrm{CCB}$ rate is still at the $0 \%$ level. Based on the information obtained by researchers, this amount is set to provide stimulus for the economy. Banks do not have the obligation to create a capital buffer because based on the assessment of the BI economy is still in sluggish condition. The inflation of Malang in 2016 was 2.62 per cent, claimed to be the lowest annual inflation in the last 10 years, this condition is lower than the 2.74 per cent recorded in East Java inflation and the national inflation rate of 3.02 per cent. With this fact, conditions in Malang especially and East Java, in general, are not at higher inflation compared to national inflation. In this conditions, it is not true to say that the economy is sluggish because inflation is a reflection of the price increase of goods and services that can affect the purchasing power and consumption level of society is still within reasonable range compared to the inflation rate of East and National Java.

\section{CONCLUSION}

The impact of implementation macroprudential policy in banking industry affect to slower the growth of bank lending rate. Macroprudential policy has no impact on individual, but it had an impact on industrial banking specifically on bank credit lending which caused by LTV regulation. The society responses to the LTV policy is that the majority do not object to the imposition of a maximum limit for housing credit enacted by bank because of the relatively long credit period. Furthermore, another instrument of macroprudential such as GWMLFR does not have an impact on banking sector and society but capital buffer instrument assuming a sluggish economy condition is assessed to have an impact on lending by banks. 


\section{REFERENCES}

BPS. 2017. Kota Malang Dalam Angka 2017. Malang: Badan Pusat Statistik.

Bank Indonesia. 2016. Mengupas Kebijakan Makroprudensial. Jakarta: Bank Indonesia.

Bruno V., \& Shin H., S,. 2014. Assessing Macroprudential Policies: Case of South Korea. The Scandanavian Journal of Economic, 116(1), 128-157.

Claessens S., Ghosh, S.R., \& Mihet, R. 2014. Macroprudential Policies to Mitigate Financial System Vulnerabilities. IMF Working Paper No. 14/155, August. 3-35.

Lim, C. H., Columba, F., Costa, A., Kongsamut, P., Otani, A., Saiyid, M., Wezel, T., \& Wu, X. 2011. Macroprudential Policy: What Instruments and How are they used? Lessons from Country Experi- ences. IMF Working Paper 11/238.

Gadanecz, B., \& Jayaram, K. 2015. Macroprudential Policy Frameworks, Intstruments and Indicators: a review. Bank for International Settlements. Desember. 1-19.

Galati G., \& Richhild M. 2011. Macroprudential Policy - a Literature Review. BIS Working Paper No.337, February. 1-38.

Lee M., Asunction, R.,C., \& Kim J. 2015. Effectiveness of Macroprudential Policies in Developing Asia: An Empirical Analysis. ADB Economics Working Paper Series No. 439, July. 1-17.
Qudrati, M., \& Suriani. 2016. Efektifitas Kebijakan Makroprudensial Perbankan dan Penyaluran Kredit di Aceh. Jurnal Perspektif Ekonomi Darussalam, 2 (1), 32-53.

Swaningrum, A., \& Peggy, H. 2014. Evaluasi Efektifitas Instrumen Makroprudensial Dalam Mengurangi Risiko Sistemik di Indonesia. 3rd Economics \& Research Festival. 1126-1133.

Suteja, J., \& Ginting, G. 2017. Determinan Profitabilitas Bank: Suatu Studi Pada Bank yang Terdaftar di BEI. Trikonomika, 13(1), 62-77.

Syafi'i, M.F.R., Rusliati, E. 2016. Credit Risk, Market Risk, Operational Risk and Liquidity Risk on Profitability of Bank In Indonesia, Trikonomika, 15(2), 78-88.

Tovar, C.E., Gracia-Escibrano, M., \& Martin, M.V. 2012. Credit Growth and The Effectiveness of Reserve Requirements and Other Macroprudential Instruments in Latin America. IMF Working Paper, June, 1-25.

Vergara, R. 2015. The Role of Macroprudential Policy and Monetary Policy in Safeguarding Financial Stability. Banking Development, Stability and Sustainability Conference. 1-14.

Vucinic, M. 2016. Importance of Macroprudential Policy Implementation for Safeguarding Financial Stability. Journal of Central Banking Theory and Practice, 3, 79-98. 